\title{
Effect of Added Grape Seed and Skin on Chicken Thigh Patties during Chilled Storage
}

\author{
Maria Nardoia $^{1,2 \S}$, Claudia Ruiz-Capillas ${ }^{2 \star}$, Ana M. Herrero², Francisco Jiménez-Colmenero², Susana \\ Chamorro $^{2}$, Agustín Brenes ${ }^{2}$
}

${ }^{1}$ Department of Agricultural, Environmental and Food Sciences, University of Molise, Via De 6 Sanctissnc - 86100 Campobasso, Italy

${ }^{2}$ Department of Products, Instituto de Ciencia y Tecnología de Alimentos y Nutrición (ICTAN) Consejo Superior de Investigaciones Científicas (CSIC), C/José Antonio Novais, 10, 28040 Madrid, Spain

${ }^{\S}$ Contributed equally

"Corresponding author: Claudia Ruiz-Capillas, Department of Agricultural, Environmental and Food Sciences University of Molise, Via De 6 Sanctissnc - 86100 Campobasso, Italy, Tel: +34915492300; E-mail: claudia@ictan.csic.es

\begin{abstract}
The effect of $2 \%$ grape seed and $2 \%$ grape skin powder added to chicken thigh patties stored at $4{ }^{\circ} \mathrm{C}$ was assessed by measuring lipid oxidation, total phenolic content, $\mathrm{pH}$, color changes and sensory attributes. The addition of these grape by-products to the patties lowered $\mathrm{pH}$ values and significantly reduced in lightness, redness and yellowness compared with the control. However, the addition of grape seed and skin significantly improved the oxidative stability of raw chicken patties due to higher total phenolic content, grape seed being more effective than skin in this regard. The phenolic content of these samples remained stable even after cooking. The acceptability of the chicken meat in general was not affected by the addition of grape by-products. These results show that grape seed and grape skin could potentially be used as natural antioxidants in raw chicken patties and would be accepted by consumers.
\end{abstract}

Keywords: Grape seed; Grape skin; Total extractable polyphenol; Chicken patties; Lipid oxidation

\section{Introduction}

By-products from the winemaking industry are widely available in Mediterranean countries. In many cases, these products cause an important environmental problem in terms of storage, processing or disposal (Brenes et al., 2016). However, grape pomace (seeds, skin, and stems) contains a wide range of polyphenols and is one of the major sources of phenolic compounds (Yildrim et al., 2005; Brenes et al., 2016). Many positive effects on human health have been described for these compounds including anti-inflammatory, anti-carcinogenic, cardio protective and vasodilatory properties (Georgiev et al., 2014). A positive effect on animal health has also been described by Brenes et al. (2016). The antioxidant and antimicrobial properties of grape polyphenols have been widely reported (Etxeberria et al., 2013; Georgiev et al., 2014). Polyphenols often act as free radical scavengers and stop radical chain reactions
Received Date: April 26, 2016

Accepted Date: June 23, 2017

Published Date: June 28, 2017

Citation: Ruiz-Capillas, C., et al. Effect of Added Grape Seed and Skin on Chicken Thigh Patties during Chilled Storage. (2017) Int J Food Nutr Sci 4(1): 67- 73.

DOI: $10.15436 / 2377-0619.17 .1497$

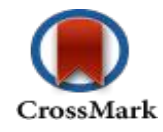

that occur during the oxidation of triglycerides. Today the meat industry is interested in replacing traditionally used synthetic antioxidants (BHT, BHA, TBHQ, etc.) which are potentially toxic and harmful to health with natural products or ingredients of plant origin containing bioactive compounds with potential health benefits (Ayo et al., 2007; Rojas \& Brewer, 2008). This is particularly important for the meat industry which is anxious to improve its image which has been tarnished over the last decade (Jiménez-Colmenero et al., 2010).

Lipid oxidation and color are important factors for consumer acceptance of meat and meat products. Several studies have found a reduction in oxidation in different meats (pork, beef, lamb, chicken and goat) after the addition of different natural compounds such as those found in oregano, sage, rosemary, thyme, marjoram, caraway, basil, ginger, kinbow, pomegranate, cereal, walnut and seaweed (Botsoglou et al., 2003; Naveena et al., 2008; Ayo et al., 2007; López-López et al., 2009;Devatkal et 
al., 2010). Grape by-products, mainly grape pomace, has proven effective in delaying lipid oxidation by reducing the accumulation of primary (e.g. lipid hydroperoxide) and secondary products of lipid oxidation [e.g., Thiobarbituric Acid Reactive Substances (TBARS)] in turkey, chicken, beef, pork, liver pate and dry cured sausage (Lau \& King, 2003; Rojas \& Brewer, 2008; Brannan, 2009; Lorenzo et al., 2014; Pateiro et al., 2014). Sáyago-Ayerdi et al. (2009) also demonstrated that the addition of grape antioxidant dietary fiber significantly improved the oxidative stability and radical scavenging activity in raw and cooked chicken burgers. Skin and seed are a rich source of flavonoids including monomeric phenolic compounds such as $(+)-$ catechins, (-)- epicatechin, and (-)- epicatechin-3-O-gallate and dimeric, trimeric and tetrameric procyanidins. Grape seed has exhibited higher antioxidant capacity compared with grape skin, mostly due to higher levels of oligomeric and polymeric procyanidins (Shahidi \& Wanasundara, 1992). However, the effect of a certain potential antioxidants could vary considerably depending on a complex interaction between various factors involving the type and concentration of active compound(s) and the nature of the food system (Schwarz et al., 2001). There is little information on the individual effect of the principal components of grape pomace (skin and seed) on meat products. Hence, the aim of this paper is to research the effect of grape skin and grape seed on the physico-chemical and sensorial properties of chicken thigh patties.

\section{Materials and Methods}

Grape Seed (GS) and Grape Skin (SS) (Vitis vinifera variety: Cencibel, La Mancha, Spain) were provided from Explotaciones Hermanos Delgado winery (Socuéllamos, Ciudad Real, Spain). GS and SS were collected from a tank during the vinification process after 15 days of alcoholic fermentation, dried (indirect air with $\mathrm{T}^{\mathrm{a}}$ less than $80^{\circ} \mathrm{C}$ ), mechanically separated and grounded at $0.5 \mathrm{~mm}$. Seeds were subjected to cool press oil extraction process before grounding. The other ingredients (eggs, breadcrumbs and salt) were obtained from a local market in Madrid (Spain). Fresh chicken thighs $( \pm 4 \mathrm{~kg})$ were likewise obtained from a local market in Madrid (Spain) and stored in the refrigerator for approximately $12 \mathrm{~h}$. The proximate composition of the chicken thighs was: moisture $73.95 \%$, protein $18.43 \%$, fat $6.63 \%$ and ash $0.97 \%$ ). Thigh meat was chosen because it is darker than breast meat and to compensate for the change in color that was expected from the addition of these by-products. The boneless chicken thighs were cut and then ground ( $4 \mathrm{~mm}$ plate) using a grinder (Mainca, Granollers, Spain). The ground meat was then used to prepare the patties.

\section{Preparation of patties}

Three formulations were used to prepare patties consisting of $85.4 \%$ meat, $6.8 \%$ whole egg, $1 \%$ salt and $6.8 \%$ breadcrumbs in the control sample (PC), $4.8 \%$ breadcrumbs and $2 \%$ grape seed in the PGS sample and $4.8 \%$ breadcrumbs and $2 \%$ grape skin in the PSS sample following the formulation of Sáyago-Ayerdi et al. (2009). The ground meat was blended in a bowl mixer (Hobart, Model N50, USA) for $60 \mathrm{~s}$ and then the salt was added and mixed a further $30 \mathrm{~s}$. The eggs and breadcrumbs were then put into the mixer and mixed for $60 \mathrm{~s}$. A total of 25 patties were made from the mixture $(\sim 50 \mathrm{~g}$ per patty) for every treatment using a conventional burger maker (Mini steak burger maker, O.L. Smith Co. Ltd., Italy). The patties were placed in high oxygen barrier vacuum bags (nylon/polyethylene, $9.3 \mathrm{ml} \mathrm{O} / \mathrm{m}^{2} / 24$ $\mathrm{h}$ at $0^{\circ} \mathrm{C}$, Koch Kansas City, MO). Each bag contained 2 patties which were refrigerated at $4^{\circ} \mathrm{C}$. The patties were analyzed on day 0 and after 3, 6 and 9 days of storage.

\section{Proximate analysis}

Moisture and ash were analyzed in meat and patties in quadruplicate according to AOAC methods (2005). Fat content was evaluated in triplicate according to the Bligh and Dyer (1959) method. Protein content was measured in quadruplicate using a Nitrogen Determinator LECO FP-2000 (Leco Corporation, St Joseph, MI, USA). Protein content was analyzed in GS and SS. The crude fiber of these ingredients was also analyzed according to AOAC methods (2005).

\section{pH}

$\mathrm{pH}$ was determined by means ofa $\mathrm{pH}$ meter $(827 \mathrm{pH}$ Lab Methrom, Herisau, Switzerland) on $10 \mathrm{~g}$ of sample homogeneously mixed with $100 \mathrm{ml}$ of distilled water. $\mathrm{pH}$ was measured for each sample.

\section{Color measurement}

Color [CIE-LAB tristimulus values, lightness ( $\left.\mathrm{L}^{*}\right)$, redness $\left(a^{*}\right)$ and yellowness $\left.\left(b^{*}\right)\right]$ was measured on the surface of raw patties using a CR-400 Chroma Meter (Konica Minolta Business Technologies, Tokyo, Japan). Ten measurements were taken per sample.

\section{Determination of total extractable polyphenols compounds}

Total Extractable Polyphenols (TEP) was extracted from GS and SS, raw and cooked patties (prepared in an electric pan 1.5 min per side at $210 \pm 4^{\circ} \mathrm{C}$ ) by means of double aqueous-organic extraction according to the method of Sáyago-Ayerdi et al. (2009). Extractable polyphenols were determined by the Folin-Ciocalteu procedure using gallic acid (Sigma-Aldrich, St. Louis, MO) as standard. Results were expressed as gallic acid equivalents (mg GAE/kg of sample).

\section{Lipid oxidation evaluation}

Lipid oxidation was determined by measuring the Thiobarbituric Acid Reactive Substances (TBARS) described by López-López et al. (2009). A calibration curve was plotted with 1,1,3,3-tetraethoxypropane (Sigma Chemical Co., St. Louis, MO, USA) to Measure Malonaldehyde (MDA). TBARS determinations were performed in triplicate. Values were expressed as mg of malondi aldehyde $/ \mathrm{kg}$ of sample.

\section{Sensory evaluation}

Patties were assessed by a 15 -member panel of individuals who regularly consume these types of products. The panel was selected after preliminary training (two sessions) on the products and terminology. Samples were cooked in an electric pan $1.5 \mathrm{~min}$ per side at $210 \pm 4^{\circ} \mathrm{C}$. Patties were cut into pieces of uniform size $(2 \times 2 \mathrm{~cm})$ and were then immediately presented to the judges who were instructed to evaluate color, flavor, hardness, juiciness and general acceptability. All parameters were measured on unstructured scales $(0=$ dislike very much, $10=$ like very much) except general acceptability which was 
measured on a hedonic scale rating test. Sensory analysis was performed 2 days after preparation of the patties.

\section{Statistical Analysis}

Data was analyzed using SPSS V.13.0 software (SPSS Institute Inc., Cary, NC). The experimental design was done in duplicate. Differences between the two replicates were not significant $(\mathrm{P}<0.05)$. Results were expressed by mean values and standard error of the mean of three or more separate determinations. One-way and two-way Variance Analysis (ANOVA) was used to determine the effect of formulation and storage time on the physico-chemical and sensorial properties of chicken thigh patties. Comparison of means was performed using the Tukey HSD test and differences were declared at $\mathrm{P}<0.05$.

\section{Results and Discussion}

\section{Proximate analysis}

The proximate composition of SS and GS is shown in Table 1. Protein content was similar for both ingredients. The main difference was observed in the polyphenolic content. Grape seed showed higher TEP and crude fiber content (approximately 4 and 2 times respectively) than grape skin. Similar results were reported by Ky et al. (2014).

Table 1: Proximate composition (\%) and total extractable polyphenols expressed as ( $\mathrm{g}$ of Gallic Acid Equivalents (GAE)/100 $\mathrm{g}$ of Grape Seed (GS) and Grape Skin (SS).

\begin{tabular}{|l|c|c|}
\hline Parameters & GS & SS \\
\hline Protein & $19.64 \pm 0.41$ & $16.27 \pm 0.01$ \\
\hline Fiber & $25.28 \pm 1.87$ & $14.40 \pm 1.33$ \\
\hline Total extractable polyphenols & $8.23 \pm 0.16$ & $2.35 \pm 0.14$ \\
\hline
\end{tabular}

Note: Means \pm SD. GS: grape seed and SS: grape skin.

Table 2 shows the proximate composition of the chicken patties. No significant differences were found in moisture, fat or protein. The addition of grape seed and skin resulted in higher $(\mathrm{P}<0.05)$ ash content compared to the control sample due to the presence of grape by-product powder in the treatments. Similar results were found in ground chicken thigh meat treated with grape seed extract (Brannan, 2008).

Table 2: Proximate analysis (\%) of different chicken thigh patties.

\begin{tabular}{|l|l|l|l|}
\hline Parameters & PC & PGS & PSS \\
\hline Moisture & $68.80 \pm 0.09^{\mathrm{a}}$ & $69.99 \pm 0.27^{\mathrm{a}}$ & $69.08 \pm 0.02^{\mathrm{a}}$ \\
\hline Protein & $18.30 \pm 0.33^{\mathrm{a}}$ & $18.72 \pm 0.06^{\mathrm{a}}$ & $18.44 \pm 0.02^{\mathrm{a}}$ \\
\hline Fat & $6.45 \pm 0.45^{\mathrm{a}}$ & $6.16 \pm 0.34^{\mathrm{a}}$ & $6.25 \pm 0.18^{\mathrm{a}}$ \\
\hline Ash & $1.90 \pm 0.04^{\mathrm{b}}$ & $2.04 \pm 0.01^{\mathrm{a}}$ & $2.03 \pm 0.08^{\mathrm{a}}$ \\
\hline
\end{tabular}

Note: Sample denomination: PC (patties Control); PGS (patties Grape Seed); PSS (patties Grape Skin)

Means \pm SD. Different letters in the same row $(a, b)$ indicate significant differences $(\mathrm{P}<0.05)$.

\section{pH}

Table 3 shows the $\mathrm{pH}$ of the different chicken thigh patties during chilled storage. Initial $\mathrm{pH}$ levels were equal to or higher than 6.20 in all samples, the lowest levels being observed in the PSS. These results are similar to those obtained for chicken patties by other authors (Calliari et al., 2015) and in cooked chicken patties elaborated with extract of kin now rind, pomegranate rind and pomegranate seed powder (Devatkal et al., 2010).

During storage time, a significant decrease in the $\mathrm{pH}$ was observed, with lower levels in samples containing GS (PGS) and SS (PSS). $\mathrm{pH}$ decreased significantly in all samples during storage time. The lowest $\mathrm{pH}$ levels were detected in PGS and PSS samples. Other authors (Lorenzo et al., 2014) also found that the addition of grape seed extract leads to lower $\mathrm{pH}$ values in pork patties. This lower $\mathrm{pH}$ is associated with microbial growth, mainly lactic acid bacteria (Triki et al., 2013), and the polyphenol content of these grape by-products.

\section{Total extractable polyphenolic compounds}

Initial levels of total extractable polyphenolic compounds were highest $(\mathrm{P}<0.05)$ in the Patties with Grape Seed (PGS) and lowest in the control sample (Table 3). These results coincide with the polyphenol content of GS and SS, which was highest in the GS (Table 2). Similar results were obtained by other authors (Thorn gate\& Singleton, 1994; Zhao et al., 1999; Yilmaz et al., 2015). Thorngate \& Singleton (1994) estimated approximately $60-70 \%$ of grape polyphenols in grape seeds and about $5 \%$ in the skin. However, the phenolic composition of grapes and different grape parts depends on multiple factors, including climate, degree of ripeness, grape size, grapevine variety and viticulture practices (Rodríguez-Montealegre et al., 2006).

Polyphenol content observed in the control patties and in those formulated with grape by-products was similar to that found by other authors in patties enriched with fruit extracts (Devatkal et al., 2010) and in the thigh meat of broilers fed wild grapes (Yong et al., 2013). However, polyphenol content in the patties of this study was lower than that observed by other authors in low-salt meat pork emulsion containing seaweed (López-López et al., 2009) and walnut (Ayo et al., 2007).

An increase in the levels of polyphenolic compounds in all the samples was observed during storage, the highest levels found in PGS samples followed by PSS in relation with initial levels. A similar pattern of total phenolic content increase during chilled storage was observed in chicken patties elaborated with extract of kin now rind, pomegranate rind and pomegranate seed powder and in cooked chicken patties treated with pomegranate juice and rind extract (Naveena et al., 2008; Devatkal et al., 2010).

In order to evaluate the effect of heat treatment on polyphenol levels, only an initial study was conducted on the second day of patty storage to simulate consumer behavior. Polyphenol levels in the cooked patties were higher $(\mathrm{P}<0.05)$ in the sample with grape seed PGS $(739.1 \mathrm{mg}$ GAE $/ \mathrm{kg}$ ) compared with PSS (527.9 mg GAE $/ \mathrm{kg}$ ) and the control (435.9 mg GAE $/ \mathrm{kg}$ ) samples. This was in relation with the polyphenolic content of raw patties (Table 3). As expected, the polyphenol levels were higher in cooked patties compared to the raw ones due to decreased moisture after cooking. The fact that patties maintain their polyphenol content after cooking suggests that this product could have health benefits for consumers. 
Table 3: $\mathrm{pH}$, Total Extractable Polyphenols (TEP) and Thiobarbituric Acid-Reactive Substances (TBARS) values of different chicken thigh patties during chilled storage $\left(4^{\circ} \mathrm{C}\right)$.

\begin{tabular}{|c|c|c|c|c|c|}
\hline \multirow[t]{2}{*}{ Parameters } & \multirow[t]{2}{*}{ Sample } & \multicolumn{4}{|c|}{ Storage (days) at $4^{\circ} \mathrm{C}$} \\
\hline & & $\mathbf{0}$ & 3 & 6 & 9 \\
\hline & $\mathrm{PC}$ & $6.64 \pm 0.01^{\mathrm{a} 1}$ & $6.39 \pm 0.06^{\mathrm{a} 2}$ & $5.30 \pm 0.05^{\mathrm{a} 3}$ & $4.99 \pm 0.03^{\mathrm{a} 4}$ \\
\hline \multirow[t]{3}{*}{ pH } & PGS & $6.52 \pm 0.01^{\mathrm{bl}}$ & $6.26 \pm 0.01^{\mathrm{a} 2}$ & $5.12 \pm 0.01^{\mathrm{b} 3}$ & $4.78 \pm 0.05^{\mathrm{b} 4}$ \\
\hline & PSS & $6.20 \pm 0.01^{\mathrm{cl}}$ & $6.05 \pm 0.01^{\mathrm{b} 2}$ & $5.14 \pm 0.01^{\mathrm{b} 3}$ & $4.83 \pm 0.02^{\mathrm{c} 4}$ \\
\hline & $\mathrm{PC}$ & $387.9 \pm 0.6^{\mathrm{c} 3}$ & $397.8 \pm 0.6^{\mathrm{b} 3}$ & $424.6 \pm 0.5^{\mathrm{c} 2}$ & $642.6 \pm 1.4^{\mathrm{cl}}$ \\
\hline \multirow[t]{3}{*}{ TEP (mg gallic acid equivalents/kg) } & PGS & $575.5 \pm 0.6^{\mathrm{a} 3}$ & $597.1 \pm 1.3^{\mathrm{a} 3}$ & $955.5 \pm 0.6^{\mathrm{a} 2}$ & $1148.1 \pm 1.0^{\mathrm{a} 1}$ \\
\hline & PSS & $400.1 \pm 1.0^{\mathrm{c} 3}$ & $411.2 \pm 0.4^{\mathrm{b} 3}$ & $577.0 \pm 1.3^{\mathrm{b} 2}$ & $841.8 \pm 0.2^{\mathrm{b} 1}$ \\
\hline & $\mathrm{PC}$ & $0.96 \pm 0.12^{\mathrm{a} 1}$ & $0.39 \pm 0.03^{\mathrm{a} 3}$ & $0.67 \pm 0.01^{\mathrm{a} 2}$ & $0.70 \pm 0.01^{\mathrm{a} 2}$ \\
\hline \multirow[t]{2}{*}{ TBARS (mg malondialdehyde/kg) } & PGS & $0.57 \pm 0.06^{\mathrm{b} 1}$ & $0.21 \pm 0.04^{\mathrm{b} 3}$ & $0.39 \pm 0.01^{\mathrm{c} 2}$ & $0.46 \pm 0.01^{\mathrm{c} 2}$ \\
\hline & PSS & $0.64 \pm 0.04^{\mathrm{bl}}$ & $0.40 \pm 0.03^{\mathrm{a} 3}$ & $0.49 \pm 0.01^{\mathrm{b} 2}$ & $0.57 \pm 0.01^{\mathrm{b} 2}$ \\
\hline
\end{tabular}

Note: Sample denomination: PC (patties Control); PGS (patties Grape Seed); PSS (patties Grape Skin)

Means \pm SD. Different letters in the same column (a, b, c) and numbers in the same row $(1,2,3)$ indicate significant differences $(\mathrm{P}<0.05)$.

\section{Lipid oxidation}

Initial patty TBARS values were very low (0.57-0.96 $\mathrm{mg}$ MDA $/ \mathrm{kg}$ sample) with significantly lower TBARS levels in the patties formulated with GS and SS (Table 3). These low TBARS were similar to the ones found by other authors (Sáyago-Ayerdi et al., 2009). TBARS generally decreased during storage in all samples. Decreases in TBARS in meat have been described at different stages of storage (Brewer \& Wu, 1993; Bhattacharya et al., 1998; Delgado-Pando et al., 2011; Salcedo-Sandoval et al., 2015), presumably due to intermolecular reactions in the malonaldehyde formed (polymerization) and reactions with other constituents, especially amino acids/proteins (Jamora \& Rhee, 2002). This phenomenon is easier to observe due to low oxidation levels in the conservation conditions used (high oxygen barrier vacuum bags). However, in general, the most significant fact of this study is that while low levels of this parameter were found in all samples, the initial differences between the samples with regard to TBARS remained constant during chilled storage with the lowest $(\mathrm{P}<0.05)$ values found in the patties treated with the grape by-products, mainly in the PGS followed by PSS. This effect correlates to the polyphenol content of grape seed and grape skin, i.e. lower TBARS values corresponded to the higher polyphenol content of the reformulated patties (Table 3). Yilmaz et al. (2015) have also described higher antioxidant activity in seed than in skin. The antioxidant effect of grape polyphenols in ground dark turkey meat, beef, pork, fish and chicken has also been described by many authors (Lau \& King, 2003; Brannan, 2008; Brenes et al. 2010; Lorenzo et al. 2014). Flavonoids have the capacity to act as powerful antioxidants by scavenging free radicals and to stop oxidative reactions (Shahidi \& Wanasundara, 1992). Grape skin and seed are a rich source of flavonoids including phenolic acids and mono meric compounds such as $(+)$ - catechins, $(-)$ - epicatechin, and (-)- epicatechin-3-O-gallate and oligomeric and polymeric procyanidins. Therefore, the increased effectiveness of GS versus SS in the reduction of lipid oxidation could be due not only to the different concentrations of phenolic compounds present in these by-products, but also to their different phenolic profile. Yilmaz \& Toledo (2004) found lower concentrations of gallic acid, monomeric catechin and epicatechin in winery by-product grape skin than in seed due to the possible release of polyphenols contain edin grape skin into the wine during the winemak- ing process.

In general, chicken thighs are more susceptible to oxidation than breast meat due to the high fatty acid content in the thigh and also the presence of pro-oxidative agents such as Fe-hemo in chicken parts where blood flow is greater. This makes it all the more interesting to include grape by-products in meat products elaborated with these cuts of meat.

\section{Color}

Color parameter results $\left(\mathrm{L}^{*}, \mathrm{a}^{*}\right.$ and $\left.\mathrm{b}^{*}\right)$ are shown in Figure $1(\mathrm{a}, \mathrm{b}$ and $\mathrm{c})$. The significant changes observed in the color parameters were attributed mainly to the grape by-products added to the patties. The addition of GS and SS in chicken meat caused a significant reduction in $\mathrm{L}^{*}$, and $\mathrm{b}^{*}$, the lowest values found in patties formulated with SS. In this latter case a significant reduction of a* was likewise found but the reduction was not significant between control and PGS patties. A general increase in all the color parameters except $b^{*}$ was observed during the storage period with lower color values for the samples treated with grape by-products compared to control patties (Figure 1). The darkening (mainly a significant reduction in $\mathrm{L}^{*}$ and $b^{*}$ ) of meat products following the addition of grape extract was also reported in ground chicken thigh and breast meat treated with grape seed extract (Brannan, 2009) and chicken burgers prepared with grape pomace dietary fiber,Sáyago-Ayerdi et al. (2009). This was also the case of cooked chicken meat treated with grape seed and peel extracts (Selani et al., 2011) and cooked pork sausages formulated with grape pomace powder (Ryu et al., 2014). This color reduction in PGS and PSS samples could be due to the dark color of both grape seed and skin. This dark color could be due to polyphenol, mainly anthocyanins, which are responsible for many of the fruit and floral colors, observed in nature. These anthocyanins are water-soluble scarlet, magenta, purple, blue and red pigments. Grapes are among the fruits with the highest levels of phenolic substances with different concentrations of total anthocyanins depending on the variety and the part of the grape (skin, pomace, etc.). In this regard, seeds contain higher levels of polyphenol than skin (Table 1) but have lower concentrations of anthocyanins and phenolic acids than skin as reported by Pinelo et al. (2006). However, despite the vividred color of grape skin and seed used in this study, a reduction of $\mathrm{a}^{*}$ was observed in the patties containing these 
grape by-products (Figure 1b). In consistent results have been reported regarding the behavior of this parameter. An increase in the value of $\mathrm{a}^{*}$ has been observed in chicken burgers prepared with grape pomace (Sáyago-Ayerdi et al., 2009). However, other authors have observed a significant decrease in CIE $a^{*}$ values in cooked products such as pork sausages reformulated with grape pomace powder (Ryu et al., 2014). This reduction was explained by the loss of anthocyanin present in grape skin when the grape juice was removed (Rababah et al., 2008). Also, Jin et al., (2013) observed a reduction of $\mathrm{a}^{*}$ in cooked sausage after adding schisandrachinensis powder which is a rich source of polyphenolic compounds, including anthocyans and flavonols. These authors noted that a reduction in a* could be due to the unstable nature of anthocyanin. On the other hand, other authors (Selani et al., 2011) did not observe significant changes in L*, $\mathrm{a}^{*}$ or $\mathrm{b}^{*}$ color parameters when grape seed and peel extracts were added to chicken or pork meat. These contrasting results could be due to the higher concentration of grape by-products (2\%) added in this study compared to other experiments (Rojas \& Brewer, 2008) where lower amounts of grape seed extract were added $(0.01 \%-0.02 \%)$. We would further note that the wine making process also affects levels of anthocyanins as does drying, increasing color intensity and the concentration of these phenolic compounds due to the effect of dehydration of grape by-products and diffusion of the colored compounds from the skin to the pulp due to structural alterations of the skin (Mazza, 1995). In our experiment, the reduction of $a^{*}$ could be attributed to different factors such as: the limited presence of these substance in animal tissue, their instability in such a medium or possible interferences of theinteraction components of GS and $\mathrm{SS}$ with the other components in the meat products (proteins, myoglobin, water or fat) influencing the color of meat products (Pietrasik \& Janz, 2009).

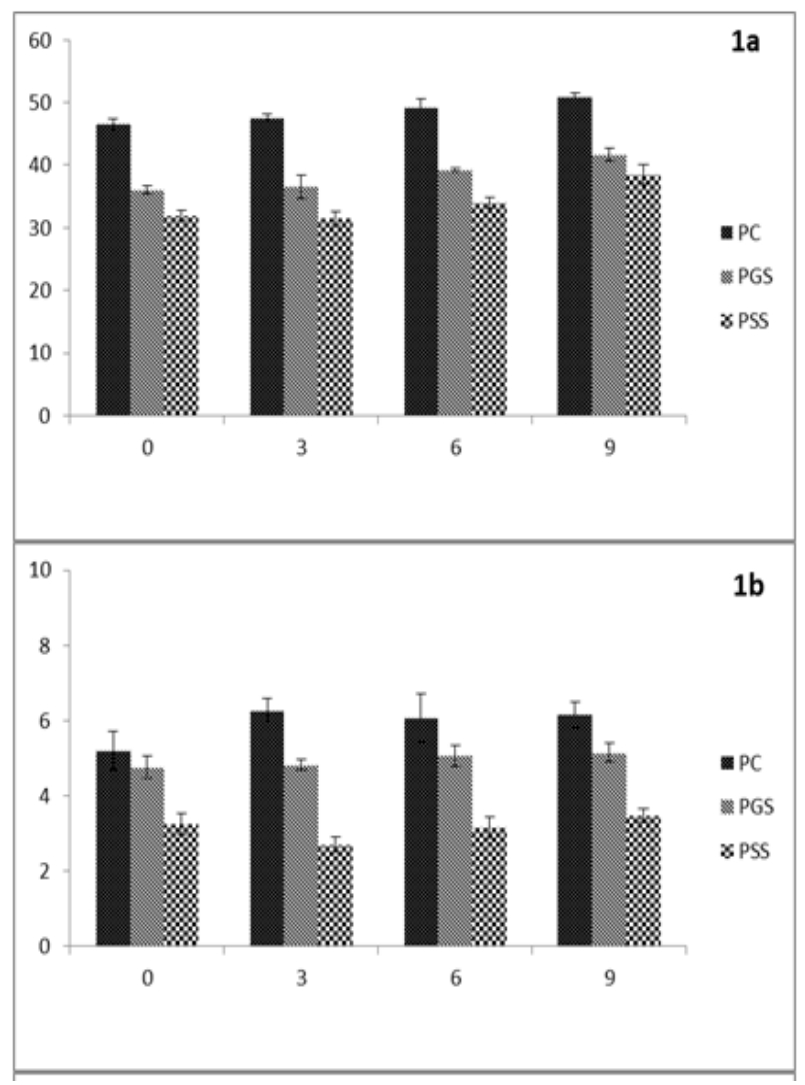

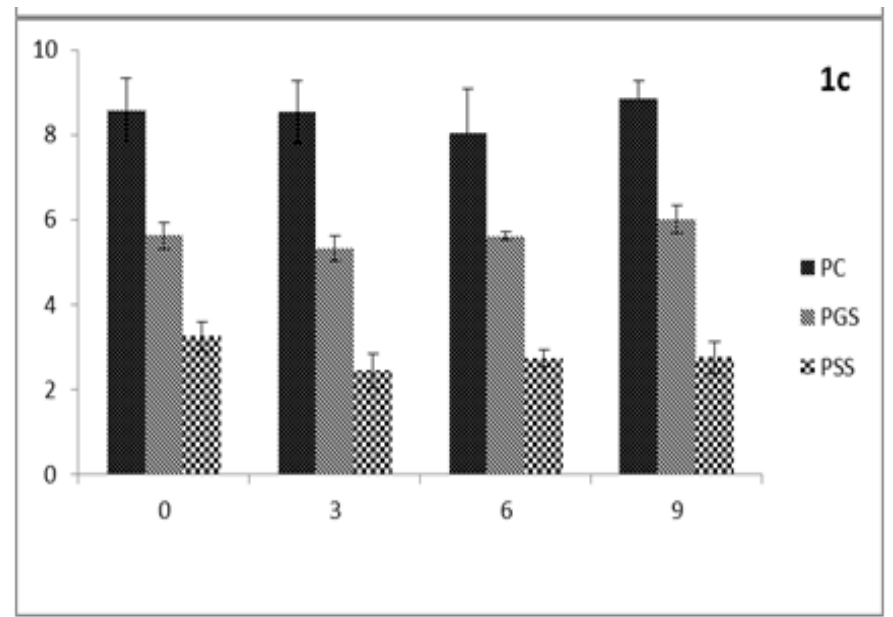

Figure 1: Lightness $\left(L^{*}\right)(1 \mathrm{a})$, Redness $\left(a^{*}\right)(1 b)$, Yellowness $\left(b^{*}\right)(1 c)$ of different chicken patties [PC (patties Control); PGS (patties Grape Seed); PSS (patties Grape Skin)] during refrigerated storage at $4{ }^{\circ} \mathrm{C}$.

\section{Sensory evaluation}

Sensory attributes of different chicken patties are shown in Figure 2. The addition of grape by-products significantly affected the sensorial color and overall acceptability parameters of the patties. No significant differences among treatments were found for other parameters. The color score could be explained by the direct addition of these grape by-products at a concentration of $2 \%$ and because of the dark color of these ingredients as already mentioned. In general, the low score $(\mathrm{P}<0.05)$ was observed for the Patties Containing Grape Skin (PSS), improbably because of the darker color of these samples. A very similar observed for the control sample and in Patties with Grape Seed (PGS). All the samples received an acceptable by the judges. In other words, the panel did not negatively evaluate the addition of grape seed powder into the patties. These results coincide with those reported by Sáyago-Ayerdi et al. (2009) and Brannan (2009).

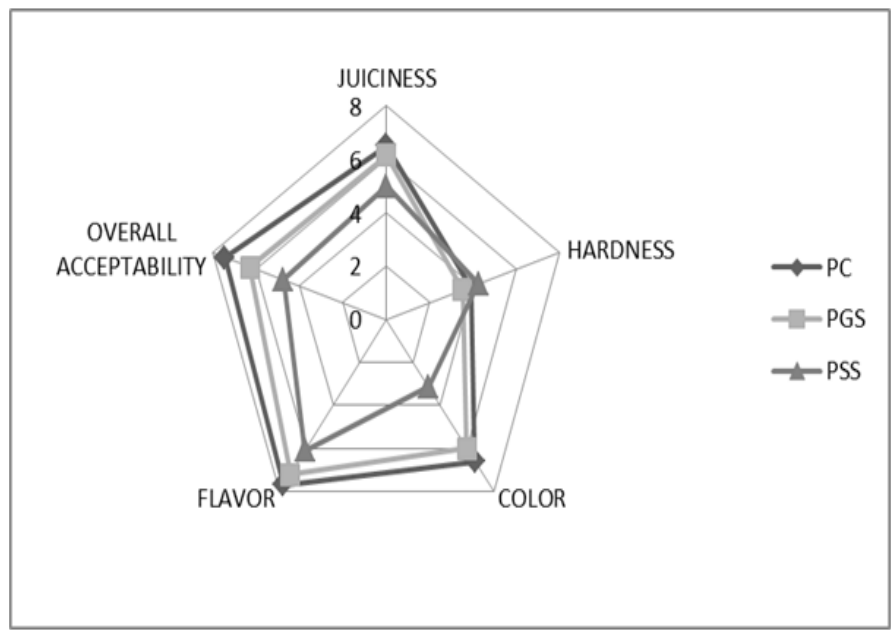

Figure 2: Sensory evaluation of different cooked chicken patties[PC (patties Control); PGS (patties Grape Seed); PSS (patties Grape Skin)].

\section{Conclusion}

The use of grape by-products such as skin and seed in the formulation of patties limited the lipid oxidation of these products. Grape seed was considered more effective in retarding 
lipid oxidation than grape skin. In general, the patties elaborated with grape seed were evaluated as being more similar to the control sample than those elaborated with grape skin. The marketing of these patties could also have a positive effect on human health due to their polyphenolic content. Therefore, these results are relevant for the meat and the agri-food industries. Wine processing by-products were traditionally considered as waste material. However, this environmental impact can be minimized thanks to this new use as natural antioxidants in meat products. Moreover, the use of these grape by-products in the development of meat products could also have positive effects for consumers thanks to their polyphenol content thus opening a new avenue in the development of healthier foods.

\section{Acknowledgments}

The authors thank the MINECO, and CSIC for financial support of Projects AGL2012-31355/GAN and the Intramural 2014470E073. Also we are grateful the CAM and ESI Funds for the financial support the project MEDGAN-CM S2013/ABI2913). Thanks to the MIUR and UNIMOL for the PhD fellowship of Maria Nardoia.

\section{Reference}

1. Horwitz, W., Latimer, G.W. Official methods of analysis of AOAC International (18th ed.). (2005) Gaithersburg, MD: AOAC.

Pubmed $\mid$ Crossref $\mid$ Others

2. Ayo, J., Carballo, J., Serrano, J., et al. Effect of total replacement of pork backfat with walnut on the nutritional profile of frankfurters. (2007) Meat Sci 77(2): 173-181.

Pubmed | Crossref $\mid$ Others

3. Bhattacharya, M., Hanna, M.A., Mandigo, R.W. Lipid oxidation in ground-beef patties as affected by time-temperature and product packaging parameters. (1988) J Food Sci 53(3): 714-717.

Pubmed $\mid$ Crossref $\mid$ Others

4. Bligh, E.G., Dyer, W.J. A rapid method of total lipid extraction and purification. (1959) Can J Biochem Physiol 37(8): 911-917.

Pubmed $\mid$ Crossref $\mid$ Others

5. Botsoglou, N.A., Grigoropoulou, S.H., Botsoglou, E., et al. The effects of dietary oregano essential oil and $\alpha$-tocopheryl acetate on lipid oxidation in raw and cooked turkey during refrigerated storage. (2003) Meat Sci 65(3): 1193-1200.

Pubmed $\mid$ Crossref $\mid$ Others

6. Brannan, R.G. Effect of grape seed extract on physicochemical properties of ground, salted, chicken thigh meat during refrigerated storage at different relative humidity levels. (2008) J Food Sci 73(1): C36-C40. Pubmed $\mid$ Crossref $\mid$ Others

7. Brannan, R.G. Effect of grape seed extract on descriptive sensory analysis of ground chicken during refrigerated storage. (2009) Meat Sci 81(4): 589-595.

Pubmed $\mid$ Crossref $\mid$ Others

8. Brenes, A., Viveros, A., Chamorro, S., et al. Use of polyphenol-rich grape by-products in monogastric nutrition. A review. (2016) Anim Feed Sci Tech 211: 1-17.

Pubmed $\mid$ Crossref $\mid$ Others

9. Brenes, A., Viveros, A., Goni, I., et al. Effect of grape seed extract on growth performance, protein and polyphenol digestibilities, and antioxidant activity in chickens. (2010) Span J Agric Res 8: 326-333.

Pubmed $\mid$ Crossref $\mid$ Others

10. Brewer, M.S., Wu, S.Y. Display, packaging, and meat block location effects on color and lipid oxidation of frozen lean ground-beef. (1993)

J Food Sci 58(6): 1219-1236.

Pubmed | Crossref | Others
11. Calliari, C.M., de Souza, E.L., Castro-Goméz, R.J., et al. Characterization and microstructure of reduced-fat chicken patties made with a novel polymer from Agrobacterium radiobacter k84. (2015) Food Chem 173: 1150-1157.

Pubmed $\mid$ Crossref $\mid$ Others

12. Cofrades, S., López-López, I., Ruiz-Capillas, C., et al. Quality characteristics of low-salt restructured poultry with microbial transglutaminase and seaweed. (2011) Meat Sci 87(4): 373-380.

Pubmed | Crossref $\mid$ Others

13. Delgado-Pando, G., Cofrades, S., Ruiz-Capillas, C., et al. Low-fat frankfurters formulated with a healthier lipid combination as functional ingredient: Microstructure, lipid oxidation, nitrite content, microbiological changes and biogenic amine formation. (2011) Meat Sci 89(1): 65-71.

Pubmed | Crossref | Others

14. Devatkal, S.K., Narsaiah, K., Borah, A. Anti-oxidant effect of extracts of kinnow rind, pomegranate rind and seed powders in cooked goat meat patties. (2010) Meat Sci 85(1): 155-159.

Pubmed | Crossref $\mid$ Others

15. Etxeberria, U., Fernández-Quintela, A., Milagro, F.I., et al. Impact of polyphenols and polyphenol-rich dietary sources on gut microbiota composition. (2013) J Agric Food Chem 61(40): 9517-9533.

Pubmed $\mid$ Crossref $\mid$ Others

16. Georgiev, V., Ananga, A., Tsolova, V. Recent advances and uses of grape flavonoids as nutraceuticals. (2014) Nutrients 6(1): 391-415.

Pubmed $\mid$ Crossref $\mid$ Others

17. Jamora, J.J., Rhee, K.S. Storage stability of extruded products from blends of meat and nonmeat ingredients: Evaluation methods and antioxidative effects onion, carrot, and oat ingredients. (2002) J Food Sci 67(5): 1654-1659.

Pubmed $\mid$ Crossref $\mid$ Others

18. Jiménez-Colmenero, F., Herrero, A., Cofrades, S., et al. Meat and functional foods. (2010) In: Hui Y H, editor. Meat and Meat Processing 225-248.

Pubmed $\mid$ Crossref $\mid$ Others

19. Jin, S.K., Park, J.H. Effect of the addition of Schisandra chinensis powder on the physico-chemical characteristics of Sausage. (2013) Asian Australas J Anim Sci 26(12): 1753-1761.

Pubmed $\mid$ Crossref $\mid$ Others

20. Ky, I., Lorrain, B., Kolbas, N., et al. Wine by-products: phenolic characterization and antioxidant activity evaluation of grapes and grape pomaces from six different French grape varieties. (2014) Molecules 19(1): 482-506.

Pubmed $\mid$ Crossref $\mid$ Others

21. Lau, D.W., King, A.J. Pre- and post-mortem use of grape seed extract in dark poultry meat to inhibit development of thiobarbituric acid reactive substances. (2003) J Agric Food Chem 51(6): 1602-1607.

Pubmed $\mid$ Crossref $\mid$ Others

22. López-López, I., Bastida, S., Ruiz-Capillas, C., et al. Composition and antioxidant capacity of low-salt meat emulsion model systems containing edible seaweeds. (2009) Meat Sci 83(3): 492-498.

Pubmed $\mid$ Crossref $\mid$ Others

23. Lorenzo, J.M., Sineiro, J., Amado, I.R., et al. Influence of natural extracts on the shelf life of modified atmosphere-packaged pork patties. (2014) Meat Sci 96(1): 526-534.

Pubmed $\mid$ Crossref $\mid$ Others

24. Mazza, G. Anthocyanins in Grapes and Grape Products. (1995) Crit Rev Food Sci Nutr 35(4): 341-371.

Pubmed $\mid$ Crossref $\mid$ Others

25. Naveena, B.M., Sen, A.R., Vaithiyanathan, S., et al. Comparative efficacy of pomegranate juice, pomegranate rind powder extract and BHT as antioxidants in cooked chicken patties. (2008) Meat Sci 80(4): 1304-1308.

Pubmed $\mid$ Crossref $\mid$ Others

26. Pateiro, M., Lorenzo, J.M., Amado, I., et al. Effect of addition of green tea, chestnut and grape extract on the shelf-life of pig liver pate. 
(2014) Food Chem 147: 386-394.

Pubmed | Crossref | Others

27. Pietrasik, Z., Janz, J.A.M. Influence of freezing and thawing on the hydration characteristics, quality, and consumer acceptance of whole muscle beef injected with solutions of salt and phosphate. (2009) Meat Sci 81(3): 523-532.

Pubmed $\mid$ Crossref $\mid$ Others

28. Pinelo, M., Arnous, A., Meyer, A.S. Upgrading of grape skins: significance of plant cell-wall structural and extraction techniques for phenol release. (2006) Trends Food Sci Technol 17(11): 579-590.

Pubmed $\mid$ Crossref $\mid$ Others

29. Rababah, T.M., Ereife,j K.I., Al-Mahasneh, M.A., et al. Total phenolics, antioxidantactivities, and anthocyanins of different grape seedcultivars grown in Jordan. (2008) Int J Food Prop 11(2): 472-479.

Pubmed $\mid$ Crossref $\mid$ Others

30. Rodríguez-Montealegre, R., Romero Peces, R., Chacon Vozmediano, J.L., et al. Phenolic compounds in skins and seeds of ten grape Vitisvinifera varieties grown in a warm climate. (2006) J Food Compost Anal 19(6-7): 687-693.

Pubmed $\mid$ Crossref $\mid$ Others

31. Rojas, M.C., Brewer, M.S. Effect of natural antioxidants on oxidative stability of frozen, vacuum-packaged beef and pork. (2008) J Food Qual 31(2): 173-188.

Pubmed $\mid$ Crossref $\mid$ Others

32. Ryu, K.S., Shim, K.S., Shin, D. Effect of Grape Pomace Powder Addition on TBARS and Color of Cooked Pork Sausages during Storage. (2014) Korean J Food Sci Anim Resour 34(2): 200-206.

Pubmed $\mid$ Crossref $\mid$ Others

33. Salcedo-Sandoval, L., Cofrades, S., Ruiz-Capillas, C., et al. Oxidative stability of $n-3$ fatty acids encapsulated in filled hydrogel particles and of pork meat systems containing them. (2015) Food Chem 184: 207-213.

Pubmed $\mid$ Crossref $\mid$ Others

34. Sáyago-Ayerdi, S.G., Brenes, A., Goñi, I. Effect of grape antioxidant dietary fiber on the lipid oxidation of raw and cooked hamburgers. (2009) LWT - Food Sci Technol 42(5): 971-976.

Pubmed $\mid$ Crossref $\mid$ Others

35. Schwarz, K., Bertelsen, G., Nissen, L.R., et al. Investigation of plant extracts for the protection of processed foods against lipid oxidation. Comparison of antioxidant assays based on radical scavenging, lipid oxidation and analysis of the principal antioxidant compounds. (2001) Eur Food Res Technol 212(3): 319-328.

Pubmed $\mid$ Crossref $\mid$ Others
36. Selani, M.M., Contreras-Castillo, C.J., Shirahigue, L.D., et al. Wine industry residues extracts as natural antioxidants in raw and cooked chicken meat during frozen storage. (2011) Meat Sci 88(3): 397-403.

Pubmed $\mid$ Crossref $\mid$ Others

37. Shahidi, F., Wanasundara P.K. Phenolic antioxidants. (1992) Crit Rev Food SciNutr 32(1): 67-103.

Pubmed $\mid$ Crossref $\mid$ Others

38. Thorngate, J.H., Singleton, V.L. Localization of procyanidins in grape seeds. (1994) [Am J Enol Vitic 45(2): 259-262.

Pubmed $\mid$ Crossref $\mid$ Others

39. Triki, M., Herrero, A.M., Jiménez-Colmenero, F., et al. Effect of preformed konjac gels, with and without olive oil, on the technological attributes and storage stability of merguez sausage. (2013) Meat Sci 93(3): 351-360.

Pubmed $\mid$ Crossref $\mid$ Others

40. Yildirim, H.K., Akcay, Y.D., Guvenc, U., et al. Antioxidant activities of organic grape, pomace, juice, must, wine and their correlation with phenolic content. (2005) Int J Food Sci Technol 40(2): 133-142.

Pubmed | Crossref $\mid$ Others

41. Yilmaz, Y., Toledo, R.T. Major flavonoids in grape seeds and skins: Antioxidant capacity of catechin, epicatechin and gallic acid. (2004) J Agric Food Chem 52(2): 255-260.

Pubmed $\mid$ Crossref $\mid$ Others

42. Yilmaz, Y., Göksel, Z., Erdoğan, S.S., et al. Antioxidant Activity and Phenolic Content of Seed, Skin and Pulp Parts of 22 Grape (Vitis vinifera L.) Cultivars (4 Common and 18 Registered or Candidate for Registration) (2015) J Food Process Preserv 39(6): 1682-1691.

Pubmed $\mid$ Crossref $\mid$ Others

43. Yong, H.I., Kim, H.J., Jung, S., et al. Effect of Dietary Supplementation of Wild Grape on the Antioxidative Potential of the Breast and Leg Meat of Broilers. (2013) Korean J Food Sci Anim Resour 33(1): 83-88.

Pubmed $\mid$ Crossref $\mid$ Others

44. Zhao J., Wang J., Chen, Y., et al. Anti-tumor-promoting activity of a polyphenolic fraction isolated from Grape Seeds in the mouse skin two-stage initiation-promotion protocol and identification of procyanidin B5-3'-gallate as the most effective antioxidant constituent. (1999) Carcinogenesis 20(9): 1737- 1745 .

Pubmed $\mid$ Crossref $\mid$ Others
Online ISSN: 2377-0619

Journal Title: International Journal Food and Nutritional Science Journal Short Name: Int J Food Nutr Sci
Ommega Online Publishers

E-mail: foodscience@ommegaonline.org

Website: www.ommegaonline.org 